\section{Strip Tillage Reduces Yield Loss of Snapbean Planted in Rye Mulch}

\author{
$\mathrm{H}$ arry Bottenberg, ${ }^{1}$ \\ John M asiunas, ${ }^{1,2}$ and \\ Catherine Eastman ${ }^{3}$
}

\begin{abstract}
AdDitional INDEX WORDS. cover crop, leaf nitrogen, potato leafhopper, Secale cereale, soil compaction, soil bulk density, white mold
\end{abstract}

\begin{abstract}
Summary. We compared soil quality, crop growth, and the incidence of pests in snapbean (Phaselusvulgaris L.) planted in conventional tillage, in rye (Secale cereale L.) mulch without strips and in strip-tilled rye mulch. On average, yield loss was $63 \%$ in rye mulch without strips and $20 \%$ in rye mulch with strips compared to yields in conventional tillage. Soil bulk density was higher in the rye mulch treatments than in the conventionally tilled plots and may have reduced plant growth. Leaf nitrogen content was lower in the rye mulch treatments 3 weeks after planting; this may be related to nitrogen tie-up during rye decomposition or to the negative impact of soil compaction on the soil nitrogen cycle. I nsect damage to snapbean pods and leaves was not affected by rye mulching. Potato leafhopper [E mpoasca fabae (H arris)] populations were significantly higher for conventional tillage than for rye treatments. The incidence of white
\end{abstract}

\footnotetext{
This research was supported by the Illinois C ounsel for Food and Agricultural Research project 97I-72. We thank Asgrow Seed for donating the snapbean seed, and D. Elliott and J. Poppe for their technical assistance. $M$ ention of a trademark, proprietary product or vendor does not constitute a endorsement, guarantee, or warranty of the product by the U niversity of I llinois or the Illinois State $\mathrm{N}$ atural $\mathrm{H}$ istory Survey and does not imply its approval to the exclusion of other products or vendors that also may be suitable. The cost of publishing this paper was defrayed in part by the payment of page charges. Under postal regulations, this paper therefore must be hereby marked advertise ment solely to indicate this fact.

${ }^{1} \mathrm{D}$ epartment of $\mathrm{N}$ atural R esources and $\mathrm{E}$ nvironmental Sciences, U niversity of Illinois, 260 ERM L, 1201 W. Gregory D rive, U rbana, IL 61801.

${ }^{2} \mathrm{~T}$ o whom reprint requests should be addressed.

3/ Ilinois $\mathrm{N}$ atural $\mathrm{H}$ istory Survey, $607 \mathrm{E}$. Peabody $\mathrm{D}$ rive, Champaign, IL 61820.
}

mold [Sclerotina sclerotiorum ( $L$ ib.) deB ary] was reduced by the rye treatments in 1997. Further studies are needed to determine optimal strip width and develop better techniques for creating strips.

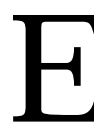
nvironmental concerns and changes in regulations necessitate developing vegetable production systems which reduce the need for tillage and pesticides. Fall-planted cover crops can eliminate spring tillage, improve soil quality, and decrease the need for pesticides in vegetable production ( $M$ asiunas et al., 1995; $\mathrm{N}$ elson et al., 1991; Putnam, 1986; Weston, 1990). Winter cereal rye is often used as a cover crop in temperate regions because it produces large amounts of biomass (Putnam, 1986; Weston, 1990), is winter hardy ( $\mathrm{N}$ elson et al., 1991) and releasesallelochemicalsthat suppress weeds (M oore et al., 1994; $M$ waja et al., 1996). In no-till rye mulch systems, yields of tomatoes (Lycopersicon esculentum M ill.) ( $M$ asiunas et al., 1995), pumpkin (C ucurbita pepo L.) (Galloway and Weston, 1996) and snapbean (N eSmith and M cC racken, 1994) were comparable to conventional tillage (CT). H owever, under certain circumstances vegetable crop yields in rye mulch systems may be reduced compared to CT systems (Bottenberg et al., 1997a, 1997b; Eckert, 1988; Gasser et al., 1995; Knavel and $\mathrm{H}$ erron, 1986; L iebman et al., 1995).

Yield reductions in cover crop systems may result from poor seed coverage, reduced soil temperatures, soil compaction, and nitrogen ( $N$ ) tieup (Bottenberg et al., 1997a, 1997b; Knavel and H erron, 1986). I ncreased wheel traffic during fall planting and spring kill of rye and the subsequent lack of tillage may lead to soil compaction that affects root development, reduces nutrient uptake, and inhibits microbial decomposition of organic matter (Breland and $\mathrm{H}$ ansen, 1996; Gasser et al., 1995; NeSmith et al., 1987; N eSmith and M cC racken, 1994; Whalley et al. , 1995). N itrogen immobilization may occur during decomposition of rye mulch and other residues that have a high carbon-to-nitrogen ratio (Browaldh, 1997; Schonbeck et al., 1993; Tian et al., 1993). In addition, rye mulch may reduce soil tem- perature and consequently the germination and initial growth of snapbeans and other warm-season crops (Bellinder et al., 1987). Poor seed coverage of mechanically planted bush bean and sweet corn (Zea mays) has been reported in no-till, perennial ryegrass (Lolium perenne L.) mulch (Knavel and Herron, 1986) and may also occur with cereal rye mulch.

If rye mulch systems are to be used for snapbean production, there is a need to modify these systems so that crop yields are more predictable and comparable with those in CT. Strip tillage is a technique that may alleviate the reduced yields of crops grown in rye mulch. Strip tillage prepares a seed bed of loose cultivated soil in a surface mulch (H oyt et al., 1994). This ensures good seed-to-soil contact and keeps the rye mulch away from close contact with the germinating seedlings. There is no information on whether or not strip tillagesystemswill overcome the reduced snapbean yields that can occur in rye mulch systems. O ur objectives were to characterize soil compaction, snapbean plant growth and yield, and insect pest populations in response to strip-tilled and untilled rye mulch.

\section{Materials and methods}

Field preparation and PLOt ESTABLISHMENT. T hisstudy was conducted at the U niversity of I llinoisC ruse V egetable R esearch Farm in Champaign, III. The soil type was a Flanagan silt loam (fine montimorrellontic, mesic, Aquic Arguidoll; pH 6.3 to 6.6 and organic matter $3.1 \%$ to $3.3 \%$ ). The experiment investigated three cropping systems: conventional tillage, rye mulch with strips(RWS), and ryemulch without strips (RWOS). In 1996, the additional factors of insect control and nitrogen application were investigated in a split-split plot design. In 1997, no insecticidesor fertilizer treatmentswere investigated. The experiment in 1997 was moved to an adjacent section of the same field.

Theconventional tillagetreatment was prepared by moldboard plowing and disking in the fall. Trifluralin active ingredient at $0.84 \mathrm{~kg} \cdot \mathrm{ha}^{-1}(0.75$ lb/ acre) was preplant incorporated with a roterra $\approx 2$ weeks before planting. The remainder of the experimental site wasmoldboard plowed, disked, and planted with 'Wheeler' cereal rye in the last week of September (1995 
and 1996) at $112 \mathrm{~kg} \cdot \mathrm{ha}^{-1}(100 \mathrm{lb} /$ acre). The rye was killed at heading stage the following spring (20 and 13 $M$ ay 1996 and 1997, respectively) with a single application of glyphosate at $1.1 \mathrm{~kg} \cdot \mathrm{ha}^{-1}(1.0 \mathrm{lb} / \mathrm{acre})$. The rye was mowed a week later with a sickle-bar mower and left to dry on the soil surface as a mulch. In 1996, bareground strips, $\approx 31 \mathrm{~cm}$ (12 inches) wide, were created at snapbean seeding in the strip-tilled treatments with a pair of fluted coulters mounted on a toolbar in front of aJ ohn D eere no-till planter (J ohn D eere, M oline, III.). In 1997, 45-cm (18-inch) widestripswere made 1 week before planting with a rear-tine rototiller. The rototiller required two passes and prior raking of the mulch away from the intended strips for effective strip tillage. On 14 and 17 J une 1996 and 1997, respectively, 1 month after mowing, 'M atador' snapbeans were planted at 78 $\mathrm{kg} \cdot \mathrm{ha}^{-1}(70 \mathrm{lb} / \mathrm{acre})$ with a no-till planter. Plots were 10 by $50 \mathrm{~m}$ (33 by $164 \mathrm{ft}$ ) with 8 snapbean rowsat $0.75 \mathrm{~m}$ (30 inches) spacing between rows. I ntrarow spacing between plantswas 5 to $7.5 \mathrm{~cm}$ ( 2 to 3 inches).

In 1996, the insecticide treated subplot received dimethoate (Cygon 400) when theeconomic threshold for the potato leafhopper of one adult per sweep or one nymph per 10 leaves was exceeded (U niversity of I llinois C ooperative Extension Service, 1996). D imethoate was applied with a tractor-mounted sprayer at $0.4 \mathrm{~kg} \cdot \mathrm{ha}^{-1}$ $(0.5 \mathrm{lb} /$ acre) on $16 \mathrm{July} 1996$ to one set of subplots. T reated and untreated subplotswere separated by a 7-m-wide $(23 \mathrm{ft})$ bare strip. The subplots were 10 by $21.5 \mathrm{~m}$ (33 by $70 \mathrm{ft}$ ). Within each subplot, a further division was made with one half receiving a single application of urea at $50 \mathrm{~kg} \cdot \mathrm{ha}^{-1}(45$ $\mathrm{lb} / \mathrm{acre}$ ) of $\mathrm{N}$, oneweek after planting; the other half did not receive urea. $U$ rea was surface applied by hand broadcasting over the plot. Based on soil test results, no other fertilizer or lime was applied to the experiment.

In 1997, soil moisture content and bulk density (a measure of soil compaction) were measured on 18 June, 17 July, and 11 Aug. A metal cylinder, $12 \mathrm{~cm}$ high, $8.6 \mathrm{~cm}$ diameter (4.5 incheshigh, 3.4 inches diameter), with both ends open, was pushed into the ground to a depth of $10 \mathrm{~cm}$ (4 inches), carefully pulled out, and the soil within the cylinder deposited into a paper bag. The samples were immediately weighed, dried for $48 \mathrm{~h}$ at $50^{\circ} \mathrm{C}$ (148 ${ }^{\circ} \mathrm{F}$ ) and weighed again. Three samples per plot were taken. Due to labor constraints, soil bulk samples were not collected in 1996.

In 1996, canopy height, width, and number of trifoliate leaves were measured on 7 Aug. (54 d after planting) from 10 randomly selected plants in the four center rows of each sub plot. Pods were harvested on 9,14 , and 21 Aug. (all plots, final harvest) from two randomly selected $5-\mathrm{m}$ (16-ft) row sections in the two center rows of each subplot. In 1997, canopy height and ground cover (\% surface area with snapbean crop) were determined on 7 and 27 Aug. from 20 randomly selected plants per plot. Plant biomass and the number of leaves per plant were measured on $7 \mathrm{~J} \mathrm{uly,} 28 \mathrm{~J}$ uly, and 8 Aug. from 16 plants per plot. The youngest fully mature leaf from each of the 10 or 16 plants was harvest for $\mathrm{N}$ determination. Theleavesfrom asingle plot were combined. Leaf $\mathrm{N}$ assessment was done by $A \& L$ G reat Lakes L aboratories, I nc. (Fort Wayne, Ind.). Pods were harvested on 26 Aug. from five randomly selected $1 \mathrm{~m}$ ( $3 \mathrm{ft}$ ) row sections per plot, excluding the two border rows. Yield loss was calculated as the percentage reduction in yield compared to CT plots.

In 1996, to assess populations of potato leafhoppers and other insects, a destructive whole-plant examination was done on 12 July (before the first insecticide application). Plants from four randomly selected $30-\mathrm{cm}$-row (1 $\mathrm{ft}$ ) sections per subplot were cut at ground level, bagged, and examined in the laboratory. O n 6 Aug., 10 trifoliate leaves were randomly sampled from 10 plants per subplot. In 1997, visual counts of insects were made in the field on 8 J uly by carefully examining 20 randomly selected plants per plot (10 plants in each of the two center rows). Between 24 and 28 J uly 1997, whole-plant destructive samples were taken from four $30-\mathrm{cm}$ row ( 1 - $\mathrm{ft}$ ) sections, one from each of the four center rows. Plants were clipped at the soil surface, placed in bags, and examined in the laboratory for insects. O n 7 Aug. 1997, sweep-net samples were taken with a standard beating-type sweep-net [ $36 \mathrm{~cm}$ (14 inches) diameter]. T wo samples, each consisting of 25 sweeps taken from rows 4 and 8, were taken per plot. Samples were placed in a plastic bag and stored in a freezer until examined. I nsectscounted included bean leaf beetles [C erotoma trifurcata (Foster)], potato leafhoppers, western corn rootworm beetles (Diabrotica virgifera virgifera L eC onte) and southern corn rootworm beetles (also called spotted cucumber beetle, Diabrotica undecimpunctata howardi Barber), caterpillars (O rder Lepidoptera), damsel bugs (Order $\mathrm{H}$ emiptera: Family $\mathrm{N}$ abidae), flower bugs (Oriussp.), and lady beetles (O $\mathrm{r}$ der Coleo ptera: Family C occinelidae). The few caterpillars, damsel bugs, flower bugs, and lady beetles that we collected were not identified to the species.

In 1997, the amount of defoliation by insects was estimated from 5 plantsin each $30-\mathrm{cm}(1-\mathrm{ft})$ row section sample (described previously). U nifoliate and trifoliate leaves were categorized based on estimated defoliation as 1) $<5 \%$ defoliation, 2) $5 \%$ to $10 \%$ defoliation, 3) $11 \%$ to $20 \%$ defoliation, 4) $21 \%$ to $30 \%$ defoliation, or 5$)>30 \%$ defoliation. No defoliation estimates were done in 1996. Estimates of pod damage by insect feeding were made in 1996 (first harvest only) and 1997. $\mathrm{H}$ arvest samples were taken from two $5-\mathrm{m}$ (15-ft) center row sections in 1996 and five randomly selected 1-m (3-ft) row sections per plot in 1997. All pods were rated on a scale of $0=$ no insect injury, $1=$ one or two minor feeding scars, or 2 = severe scars or deep feeding sites (unmarketable). Total pods and number of pods with white mold were counted in the samples.

The1996 experiment wasathreefactorial, split-split plot design with three replications. The whole plots were the management system; insecticide and nitrogen treatments were the subplots. The 1997 experiment was a single-factorial randomized complete block design with four replications. The general linear model (GLM) procedure of the Statistical Analysis System (SAS Institute, Cary, N.C.) was used. T reatment meanswereseparated using Fisher's least significant difference ( $L S D)$ test at $p=0.05$. Correlation analysis was used to test relationships between selected variables.

\section{Results and discussion}

In 1997, soil bulk density and moisture from samples taken within thecrop row were affected by manage- 
T able 1. Soil bulk density and soil moisture in conventional tillage (CT), rye mulch with strips (R WS), and rye mulch without strips (R WOS) in 1997.

\begin{tabular}{|c|c|c|c|}
\hline Date & $\begin{array}{c}\text { M anagement } \\
\text { system }\end{array}$ & $\begin{array}{c}\text { Soil bulk } \\
\text { density } \\
\left(\mathrm{g} \cdot \mathrm{cm}^{-3}\right)^{z}\end{array}$ & $\begin{array}{c}\text { Soil } \\
\text { moisture } \\
(\%)\end{array}$ \\
\hline \multirow[t]{3}{*}{4 June } & CT & $1.43 a^{y}$ & 18.37 b \\
\hline & RWS & $---x$ & --- \\
\hline & RWOS & $1.52 \mathrm{a}$ & 20.96 a \\
\hline \multirow[t]{3}{*}{18 J une } & $\mathrm{CT}$ & $1.36 \mathrm{~b}$ & $15.77 \mathrm{c}$ \\
\hline & RWS & $1.37 \mathrm{~b}$ & 17.79 b \\
\hline & RWOS & $1.50 \mathrm{a}$ & 19.64 a \\
\hline \multirow[t]{3}{*}{17 July } & CT & $1.42 \mathrm{~b}$ & $11.57 \mathrm{C}$ \\
\hline & RWS & $1.61 \mathrm{a}$ & $14.43 \mathrm{~b}$ \\
\hline & RWOS & $1.56 \mathrm{a}$ & $17.82 \mathrm{a}$ \\
\hline \multirow[t]{3}{*}{11 Aug. } & $\mathrm{CT}$ & $1.30 \mathrm{~b}$ & $14.66 \mathrm{~b}$ \\
\hline & RWS & $1.52 \mathrm{a}$ & $15.01 \mathrm{~b}$ \\
\hline & RWOS & $1.58 \mathrm{a}$ & 17.96 a \\
\hline
\end{tabular}

${ }^{2} 1.0 \mathrm{~g} \cdot \mathrm{cm}^{-3}=62.43 \mathrm{lb} / \mathrm{ft}^{3}$

yM ean separation within dates by Fisher's protected least significant difference test $(p=0.05)$.

xStrips were not yet established.

Table 2. C anopy height and ground cover on 7 August 1996 ( $54 \mathrm{~d}$ after planting) in conventional tillage (CT), rye mulch with strips (RWS), and rye mulch without strips (R WOS) treated $(+)$ and untreated $(-)$ with insecticide. ${ }^{z}$

\begin{tabular}{lccc}
\hline $\begin{array}{l}\text { Management } \\
\text { system }\end{array}$ & Insecticide & $\begin{array}{c}\text { C anopy } \\
\mathbf{h t} \\
(\mathbf{c m})^{\mathbf{y}}\end{array}$ & $\begin{array}{c}\text { G round- } \\
\text { cover } \\
(\%)\end{array}$ \\
\hline CT & + & $18.4 \mathrm{a}^{\mathrm{x}}$ & $39 \mathrm{a}$ \\
CT & - & $13.7 \mathrm{C}$ & $32 \mathrm{~b}$ \\
RWS & + & $16.0 \mathrm{~b}$ & $32 \mathrm{~b}$ \\
RWS & - & $14.5 \mathrm{bc}$ & $30 \mathrm{bc}$ \\
RWOS & + & $15.8 \mathrm{~b}$ & $32 \mathrm{~b}$ \\
RWOS & - & $13.2 \mathrm{C}$ & $24 \mathrm{C}$ \\
\hline
\end{tabular}

${ }^{2}$ imethoate was applied on $16 \mathrm{~J}$ uly for control of potato leafhoppers.

$\mathrm{y}_{2.5} \mathrm{~cm}=1$ inch.

$\times M$ ean separation within dates by Fisher's protected least significant difference test $(p=0.05)$.

Table 3. Percentage leaf nitrogen $(\mathrm{N})$, shoot dry weight $(\mathrm{g})$ and number of leaves per plant in snapbean planted in conventional tillage (CT), rye mulch with strips (R WS), and rye mulch without strips (R WOS) in 1997.

\begin{tabular}{lcccc}
\hline Date & $\begin{array}{c}\text { Management } \\
\text { system }\end{array}$ & $\begin{array}{c}\text { Leaf } \\
\mathbf{N} \\
\mathbf{( \% )}\end{array}$ & $\begin{array}{c}\text { Shoot } \\
\text { dry } \\
\text { wt } \\
\text { (g/plant) }\end{array}$ & $\begin{array}{c}\text { Leaves } \\
\text { per } \\
\text { plant }\end{array}$ \\
\hline 8 July & CT & $4.60 \mathrm{a}^{\mathrm{y}}$ & $0.80 \mathrm{a}$ & $2.09 \mathrm{a}$ \\
& RWS & $3.71 \mathrm{~b}$ & $0.51 \mathrm{~b}$ & $1.36 \mathrm{~b}$ \\
28 July & RWOS & $3.96 \mathrm{~b}$ & $0.60 \mathrm{~b}$ & $1.58 \mathrm{~b}$ \\
& CT & $3.67 \mathrm{a}$ & $---\mathrm{x}$ & $8.54 \mathrm{ab}$ \\
8 Aug. & RWS & $3.76 \mathrm{a}$ & --- & $9.69 \mathrm{a}$ \\
& RWOS & $3.65 \mathrm{a}$ & --- & $7.69 \mathrm{~b}$ \\
& CT & $4.53 \mathrm{a}$ & $9.58 \mathrm{a}$ & $15.06 \mathrm{a}$ \\
& RWS & $3.99 \mathrm{a}$ & $6.62 \mathrm{~b}$ & $15.23 \mathrm{a}$ \\
& RWOS & $4.41 \mathrm{a}$ & $4.76 \mathrm{~b}$ & $10.92 \mathrm{~b}$
\end{tabular}

z28.35 g = $1.0 \mathrm{oz}$.

yM ean separation within dates by Fisher's protected least significant difference test $(p=0.05)$.

${ }^{\times} \mathrm{N}$ o samples collected.

ment system. On 4 June, 2 weeks before planting and $3 \mathrm{~d}$ before establishment of the strips, soil bulk density was similar in CT $\left(1.43 \mathrm{~g} \cdot \mathrm{cm}^{-3} ; 89.3\right.$ $\left.1 \mathrm{~b} / \mathrm{ft}^{3}\right)$ and rye mulch plots $(1.52$ $\mathrm{g} \cdot \mathrm{cm}^{-3} ; 94.9 \mathrm{lb} / \mathrm{ft}^{3}$ ) (Table 1). O 18
June, one day after planting and $11 \mathrm{~d}$ after strips were made, soil bulk density was similar in CT and RWS but significantly higher in RWOS. H owever, in July and August, soil bulk density in the RWS had increased and was similar to that in the RWO S plots. At the initial sampling of 4 June, soil moisture was $2.5 \%$ greater under rye mulch than in conventional tillage. O n 18 June, soil moisture was highest in RWOS (19.6\%), intermediate in RWS (17.8\%) and lowest in CT (15.8\%). This trend continued on 17 July. Soil moisture was consistently higher in the RWOS than in the other treatments.

In 1996, the addition of nitrogen did not have a significant effect on canopy height, ground cover, or number of leaves (data not shown). I nsecticide application for control of potato leafhoppers interacted with cropping system to affect plant development. Canopy height and percentage ground cover were greatest in CT treated with insecticide (T able 2); crop growth was suppressed in the rye treatments. Insecticide did not have an effect on canopy height or ground cover in the RWS. O n 8 August 1997, the number of leaves per plant ranged from 7.2 in RWO S to 10.8 in CT; however, differences were not significant (data not shown). Canopy height varied from 32 to $34 \mathrm{~cm}$ (12.5 to 13.4 inches) and ground cover from $43 \%$ to $45 \%$ (data not shown). A gain the differenceswere not significant.

On 8 J uly 1997, when plantswere in the seedling stage, leaf $\mathrm{N}$ wassignificantly higher in CT $(4.60 \%)$ than in the rye treatments (3.71\% to $3.96 \%)$ (Table 3). Leaf yellowing was apparent on the plantsin the rye treatments. $\mathrm{H}$ owever, on $28 \mathrm{July}$ and $8 \mathrm{Aug}$. there were no differences in leaf $\mathrm{N}$, although bean plants in the rye plots were still chlorotic. Shoot dry weight was highest in CT on both sampling dates. L eaf number per plant differed between management systems on all three sample dates. On 8 July plants in CT had the most leaves while late in the season plants in CT and RWS had similar numbers of leaves.

In 1996, total pod yield washighest in CT and least in the RWOS treatment ( $T$ able 4). The addition of nitrogen did not influence pod yield; insecticide application improved yield in the CT [ 7290 and $4450 \mathrm{~kg} \cdot \mathrm{ha}^{-1}$ (6770 and $3970 \mathrm{lb} /$ acre) with and without insecticide, respectively] but 
T able 4. Snapbean pod yield as influenced by management systems [conventional tillage (CT), rye mulch with strips (RWS), and rye mulch without strips (R W OS) treated (+) and untreated (-) with insecticide] in 1996 and 1997.

\begin{tabular}{|c|c|c|c|}
\hline Year & $\begin{array}{c}\text { M anagement } \\
\text { system }\end{array}$ & Insecticide & $\begin{array}{c}\text { Pod } \\
\text { yield } \\
\left(\mathrm{kg} \cdot \mathrm{ha}^{-1}\right)^{z}\end{array}$ \\
\hline \multirow[t]{6}{*}{$1996^{y}$} & CT & $t^{x}$ & $7290 a^{w}$ \\
\hline & CT & - & $4450 \mathrm{~b}$ \\
\hline & RWS & + & 2950 bc \\
\hline & RWS & - & 3440 bc \\
\hline & RWOS & + & $2120 \mathrm{~cd}$ \\
\hline & RWOS & - & $1080 \mathrm{~d}$ \\
\hline \multirow[t]{3}{*}{1997} & $\mathrm{CT}$ & - & 8720 a \\
\hline & RWS & - & $6960 a b$ \\
\hline & RWOS & - & $3850 \mathrm{~b}$ \\
\hline
\end{tabular}

${ }^{\mathrm{z}} 1.0 \mathrm{~kg} \cdot \mathrm{ha}^{-1}=0.893 \mathrm{lb} /$ acre

YT otal of first and final harvest.

XD imethoate was applied on 16 July for control of potato leafhoppers.

wM ean separation within dates by Fisher's protected least significant difference test $(p=0.05)$. not in the rye treatments, which had lower populations of potato leaf hopper (PLH). The lowest yield wasin the untreated RWO S (1077 kg.ha ${ }^{-1} ; 964$ $\mathrm{lb} / \mathrm{acre})$; the greatest yields were in theCT with insecticide. In 1997, yields were again the highest in the $C T$ treatment $\left(8720 \mathrm{~kg} \cdot \mathrm{ha}^{-1} ; 7790 \mathrm{lb} / \mathrm{acre}\right)$, intermediate in theRWS $\left(6960 \mathrm{~kg} \cdot \mathrm{ha}^{-1}\right.$; $6210 \mathrm{lb} / \mathrm{acre}$ ) and lowest in theRWOS (3850 kg.ha-1; $3440 \mathrm{lb} /$ acre).

In 1996, the percentage marketable yield, which includes pods with no or only minor damage (ratings of 0 and 1 ), was significantly higher in the treated CT (91.5\%) than in the treated or untreated RWS $(82.7 \%$ to $83.3 \%)$; other treatments were intermediate (data not shown). Pod injury from insect feeding was more serious in 1997 than in 1996. The percent of snapbeansmarketableranged from $53 \%$ to $65 \%$ in 1997 and was not affected by management system.

Compared to the $C T$, yield lossin the RWOS was significantly greater than the loss in the RWS. In 1996, yields in the RWS and RWOS plots were 21.9 and $76.0 \%$ respectively and in 1997 yields were 17.8 and $53.8 \%$ less than the CT. When the two years were averaged, the yield loss in the RWS plots (19.6\%) was significantly less than yield loss in the RWOS plots (63.3\%). Soil bulk density $\left(\mathrm{g} \cdot \mathrm{cm}^{-3} ; \mathrm{lb} /\right.$ $\mathrm{ft}^{3}$ ) had a negative correlation with pod yield $\left(r=-0.79^{* *}\right)$.

The percentage pods with white mold differed among treatments. In the CT $6.5 \%$ of the pods had white mold while only $0.6 \%$ of pods in the RWOS and $0.5 \%$ of pods in the RWS plots had white mold. Although white mold reduced marketable yield in CT its effect wassmall compared to the rye treatment effects.

In 1996, potato leafhopper populations were lower in the RWO S than in the $\mathrm{CT}$ treatment ( $\mathrm{T}$ able 5 ). $\mathrm{N}$ itrogen did not have an impact on PLH populations on 12 July or on 6 Aug. Insecticide application reduced PLH numbers on $6 \mathrm{Aug}$. in the CT and RWS plots but not in the RWOS plots. $\mathrm{PLH}$ populations were correlated to the number of snapbean leaves $(r=$ 0.81 in treated plots and $r=0.79$ in insecticide-free plots).

The visual assessment on 12 J uly (4 $\mathrm{d}$ before insecticide was applied) found that populations of the flower bugs, an important PLH predator, ranged from 0.3 to 0.8 bugs per plant but did not differ among treatments. Bean leaf beetles, lady beetles, damsel bugs, and spiders (ClassA rachnida; identified no further) were observed in numbers too low for meaningful analysis.
In 1997, PLH populations were lower than those observed in 1996 but still approached economic thresholds (U niversity of Illinois Cooperative Extension Service, 1996). There were differences between treatmentsin PL H populations only at the onset of the season on 9 J uly. PLH densities(adults + nymphs) were greater on snapbean plants in CT (3.56 PLH / plant) than in the rye plots $(0.81$ to $1.31 \mathrm{PLH} /$ plant). O n 28 July and 10 Aug., leafhopper density was not affected by cropping system. PLH numbers were correlated to the biomass of the plants on 10 August $\left(r=0.85^{* *}\right)$.

Leaf mining (probably by a D ipteran) wascommon in the rye plots in 1997 but was not observed in 1996. Leaf mining damage was greater in RWOS $(17.5 \%$ of number of plants affected) than in the RWS (11.8\%) and CT $(2.5 \%)$ treatments. Leaf mining did not correlatewith snapbean growth or yield.

On $28 \mathrm{~J} \mathrm{uly,} \mathrm{leaf} \mathrm{damage} \mathrm{by} \mathrm{chew-}$ ing insects such as corn rootworm beetles varied from $13.5 \%$ of leaf area affected in the CT to $22.3 \%$ in the RWO S; however, differenceswerenot significant. On 24 to $28 \mathrm{~J} \mathrm{uly,} \mathrm{bean} \mathrm{leaf}$ beetle and western corn rootworm populations were low and did not differ among treatments. L eaf damage wasnot related to beetle counts. 0 ther arthropodsincluding damsel bugs, spiders, black flea beetles (Systena sp.) and grape colaspis [C olaspis brunnea (Fabricius)] averaged less than 0.05 per plant.

O ur previousstudies (Bottenberg et al., 1997a, 1997b; M asiunas et al., 1997) found that differences in soil temperatures between $\mathrm{CT}$ and rye treatments could not explain differences in snapbean growth and yield. O ur mid-June planting date in this
Table 5. N umber of potato leafhoppers per plant on $12 \mathrm{July}$ and 6 Aug. 1996, in conventional tillage (CT), rye mulch with strips (RWS), and rye mulch without strips (RWOS) with (+) and without (-) insecticide. ${ }^{z}$

\begin{tabular}{lccc}
\hline $\begin{array}{l}\text { Management } \\
\text { system }\end{array}$ & Insecticide & 12 J uly & $\mathbf{6 ~ A u g . ~}$ \\
\hline CT & + & --- & $14.2 \mathrm{bc}^{\mathrm{y}}$ \\
CT & - & $8.1 \mathrm{a}$ & $32.3 \mathrm{a}$ \\
RWS & + & --- & $6.7 \mathrm{c}$ \\
RWS & - & $5.2 \mathrm{ab}$ & $21.8 \mathrm{ab}$ \\
RWOS & + & --- & $8.0 \mathrm{C}$ \\
RWOS & - & $3.5 \mathrm{~b}$ & $8.0 \mathrm{C}$
\end{tabular}

${ }^{2}$ D imethoate was applied 16 July for control of potato leafhoppers.

yM ean separation within dates by Fisher's protected least significant difference test $(p=0.05)$. 
study supports the conclusion that growth and yield reductions of snapbean were not due to suboptimum temperatures in the rye treatments.

Soil compaction in the rye plots reduced snapbean growth and pod yield. O ther studies also found higher soil bulk densities under fall-planted cover crop mulches of small grains (D ao, 1996; Gasser et al., 1995; $\mathrm{N}$ eSmith et al., 1987). The increased tractor wheel traffic during fall planting, herbicide application and spring mowing resulted in soil compaction. Growth-limiting bulk densities vary with the type of soil and depend primarily on soil texture ( $D$ addow and Warrington, 1983). I n our study, bulk densities in the untilled rye plots exceeded the growth-limiting threshold of 1.45 for a silt loam soil ( $D$ addow and Warrington, 1983). Strip tillage broke up the compacted top soil layer before planting but subsequent soil consolidation through rainfall and foot traffic increased soil bulk density compared to the CT treatment. The high bulk density probably affected root development and nutrient uptake by the snapbean crop and contributed to leaf chlorosis and lower leaf $\mathrm{N}$ levels. In addition, $\mathrm{N}$ mineralization can be reduced in compacted soil because of anaerobic conditions and protection of organic material from microbial attack (Breland and $\mathrm{H}$ ansen, 1996).

$\mathrm{N}$ itrogen immobilization by microorganisms during decomposition of the rye residue may also have contributed to the leaf chlorosis and lower leaf $\mathrm{N}$ levels in the rye plots (Wyland et al., 1995). The addition of $\mathrm{N}$ in the form of urea 1 week after planting in 1996 did not promote plant growth and yield. The $\mathrm{N}$ may have volatilized, been immobilized, or leached before snapbean seedlings were able to absorb it. A split application later during the season may have been more effective. Yield reduction in the strip-tilled rye waslessthan in theno-till ryeplots. It is possiblethat allelochemicalsleaching from the rye surface residue into the snapbean root zone in the no-till plots were phytotoxic to the snapbean plants and contributed to chlorosis and yield suppression.

Potato leafhopper populations werehigher in 1996 than in 1997. The single insecticide treatment in 1996 significantly reduced PL H populations and increased pod yield in the CT treatment but not in the no-till rye plots, wherePLH numbersweremuch lower. Plant growth in rye plots was retarded, resulting in smaller plants with fewer leaves that supported smaller insect populationsthan in the C T plots. This confirmed previous findings with snapbean (Bottenberg et al, 1997a) and cabbage (Bottenberg et al, 1997b; Roberts and Cartwright, 1991) that smaller plant sizes and lower insect populations were correlated. It is also possible that the lower PLH populations in the rye plots are in part related to the lower leaf $\mathrm{N}$ content of the snapbean, which may reduce host plant suitability and leafho pper colonization rates. Interference with host plant finding by the rye mulch (Andow, 1991) may also have been involved to some degree but wasnot tested in our study. Preservation of beneficial insects in cover crop mulch systems(Bugg, 1992) can lead to higher predation rates, but in our study, populations of predatory insects (damsel bugs, flower bugs, lady beetles) were relatively low and predator to prey ratiosdid not show asignificant response to rye mulching.

L eaf-feeding damage and beetle populations (bean leaf beetleand western corn rootworm adults), on a per plant and per leaf basis, were not affected by rye mulching. This confirms previous observations in these systems (Bottenberg et al., 1997a).

Asin apreviousstudy (Bottenberg et al., 1997a), incidence of whitemold, a soilborne fungal pathogen, was reduced in plots with rye mulch. The mulch acted as a barrier between the pods and soil surface minimizing soil splashing by rain and spore dispersal. In addition, the more open canopy in the rye plots (where plant growth was reduced), may have reduced humidity levelsin the canopy making conditions for fungal infections less favorable (Sherf and $\mathrm{M} \mathrm{cN} \mathrm{ab}, 1986$ ). M ulching with cover crop residueis also believed to reduce some soilborne pathogens due to enhanced soil microbiological activity (Thurston, 1992).

Improvement is needed in the strip-tillage method. Although simultaneous comparisons were not performed, the 5-horsepower rototiller created strips that were deeper and cleaner than strips made with the toolbar-mounted fluted coulters. $\mathrm{H}$ owever, even thetillage depth [10 to $20 \mathrm{~cm}$ (4 to 8 inches)] attained with the rototiller in our heavy soils was probably not sufficient to ensure adequate root development. I n addition, the method was labor-intensive and may not be economically feasible for commercial growers. A tractormounted rototiller may produce strips of greater and more uniform depth during a shorter period of time.

In conclusion, poor snapbean growth and yield in rye mulch was caused by soil compaction that occurred during glyphosate application and mowing. Strip tillage of the rye will reduce early season soil compaction and improve yield. Lower nitrogen content of snapbean leaves in the rye was most likely due to poor root and/ or nodule development and the addition of nitrogen fertilizer could not overcomethe reduced yields. Strip tilled rye mulch effected pest populations similar to solid rye. These lower pest populationscould reducetheneed for some pesticide applications.

\section{Literature cited}

Andow, D .A. 1991. Vegetational diversity and arthropod response. Annu. Rev. Entomol. 36:561-586.

Bellinder, R.R., H.P. Wilson, and T.E. $H$ ines. 1987. Comparative studies of conventional and no-tillage systems for snap bean production. $\mathrm{H}$ ortScience 22:159.

Bottenberg, H ., J. M asiunas, C. E astman, and D .M. Eastburn. 1997a. The impact of rye cover crops on weeds, insects, and diseases in snap bean cropping systems. J . Sustainable Agr. 9(2/ 3):131-155.

Bottenberg, H., J. M asiunas, C. E astman, and D.M. Eastburn. 1997b. Yield and quality constraints of cabbage planted in rye mulch. Biol. Agr. H ort. 14:323-342.

Breland, T.A. and S. H ansen. 1996. N itrogen mineralization and microbial biomass as affected by soil compaction. Soil Biol. Biochem. 28(4):655-663.

Browaldh, M . 1997. N itrogen release from leavesand prunings of different tree species used as green manures. Biol. Agr. Hort. 14:309-322.

Bugg, R.L. 1992. U sing cover crops to manage arthropods on truck farms. H ortScience 27(7):741-745.

D addow, R.L. and G.E. Warrington. 1983. Growth-limiting soil bulk densities as influenced by soil texture. USDA Forest Serv. WS DG -TN -00005.

D ao, T.H. 1996. Tillage system and crop residue effects on surface compaction of a paleustoll. Agron. J. 88:141-148. 
E ckert, D.J . 1988. R ye cover crops for notillage corn and soybean production. J. Prod. Agr. 1(3):207-210.

Galloway, B.A. and L.A. Weston. 1996. I nfluence of cover crop and herbicide treatment on weed control and yield in no-till sweet corn (Zea mays L.) and pumpkin (C ucurbita maxima D uch.). Weed Technol. 10:341-346.

G asser, M .O ., A.N . D ayegamiye, and M .R. $L$ averdiere. 1995. Short-term effects of crop rotations and wood-residue amendments on potato yields and soil properties of a sandy loam soil. Can. J. Soil Sci. 75:385-390.

H oyt, G.D., D.W. M onks, and T.J. M onaco. 1994. Conservation tillage for vegetable production. HortT echnology $4(2): 129-135$

Knavel, D.E. and J.W. H erron. 1986. Response of vegetable crops to nitrogen rates in tillage systems with and without vetch and ryegrass. J. Amer. Soc. H ort. Sci. 111(4):502-507.

Liebman, M., S. Corson, R.J. Rowe, and W.A. H alteman. 1995. D rybean responses to nitrogen fertilizer in two tillage and residue management systems. Agron. J. 87:538-546

M asiunas, J.B., L.A. Weston, and S.C. Weller. 1995. The impact of rye cover crops on weed populations in a tomato cropping system. Weed Sci. 43:318-323.

M asiunas, J.B., D.M. Eastburn, V.N M waja, and C.E. Eastman. 1997. The impact of living and cover crop mulch systems on pests and yields of snap beans and cabbage. J. Sustainable Agr. 9(2) 3):61-89.

Moore, M.J., T.J. Gillespie, and C.J. Swanton. 1994. E ffect of cover crop mulch on weed emergence, weed biomass, and soybean (Glycinemax) development. Weed Technol. 8:512-518.

M waja, V.N., J.B. M asiunas, and C.E. Eastman. 1996. Rye (Secale cereale) and hairy vetch (Vicia villosa) intercrop management in fresh market vegetables. J. Amer. Soc. H ort. Sci. 121: 586-591.

N elson, W.A., B.A. Kahn, and B.W. Robert. 1991. Screening cover crops for use in conservation tillage systems for vegetables following spring plowing. H ortScience 26:860-862.
NeSmith, D.S., W.L. H argrove, D.E. Radcliffe, E.W.Tollner, and H .H . A rioglu. 1987. Tillage and residue management effects on properties of an ultisol and double-cropped soybean production. Agron. J. 79:570-576.

N eSmith, D.S. and D.V. M cC racken. 1994. Snap bean response to soil tillage management and cover crops. Commun. Soil Sci. Plant Anal. 25(13-14):2501-2512.

Putnam, A.R. 1986. Allelopathy: Can it be managed to benefit horticulture? $\mathrm{H}$ ortScience 21:411-412.

Roberts, B.W. and B. Cartwright. 1991. Alternative soil and pest management practices for sustainable production of freshmarket cabbage. J. Sustainable Agr. 1:2135.

Schonbeck, M ., S. H erbert, R. D eG regorio, F. M angan, K. Guillard, E. Sideman, J. H erbst, and R. J aye. 1993. Cover cropping systems in the northeastern U nited States: 1. Cover crop and vegetable yields, nutrients and soil conditions. J. Sustainable Agr. 3: 105-132.

Sherf, A.D. and A.A. M cN ab. 1986. Vegetable diseases and their control. Wiley, N ew York.

Thurston, H.D. 1992. Sustainable practices for plant management in traditional farming systems. W estview Press, Boulder, Colo.

Tian, C., B.T. Kang, and L. Brussaard. 1993. Mulching effect of plant residues with chemically contrasting compositions on maize growth and nutrients accumulation. Plant Soil 153:179-187.

U niversity of I llinois Cooperative Extension Service. 1996. M idwest vegetableproduction guide for commercial growers. C1356. U niv. III. Coop. Ext. Serv., U rbana.

Weston, L.A. 1990. Cover crop and herbicide influence on row crop seedling establishment in no-tillage culture. Weed Sci. 38:166-171.

Whalley, W.R., E. D umitru, and A.R. D exter. 1995. Biological effects of soil compaction. Soil Tillage Res. 35: 53-68.

Wyland, L.J., L.E. Jackson, and K.F. Schulbach. 1995. Soil-plant nitrogen dynamics following incorporation of a mature rye cover crop in a lettuce production system. J. Agr. Sci. 124:17-25. 